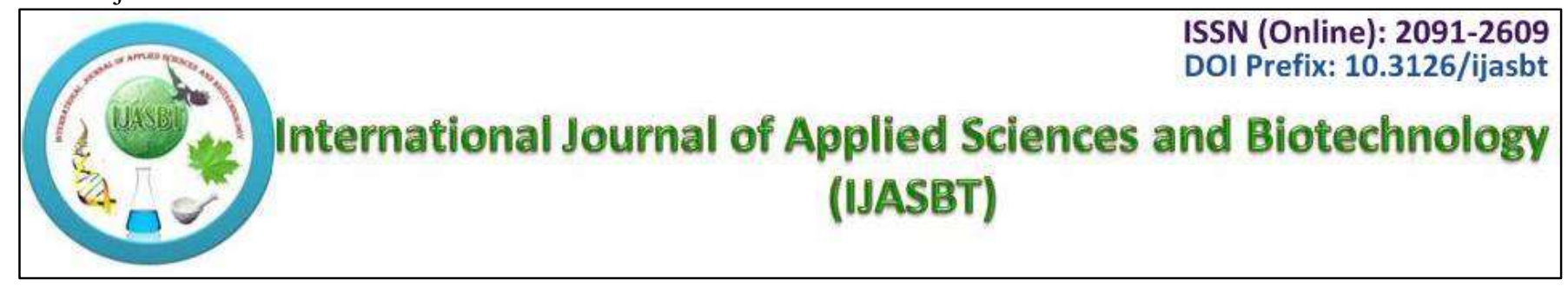

Research Article

\title{
Evaluation of Antibacterial Activity of Cymbopogon citratus Ethanolic Leaf Crude Extract against Streptococcus pneumoniae isolated from Kampala International University Teaching Hospital Western Campus, Bushenyi-Uganda
}

\author{
Ibrahim Ntulume $^{1^{*}}$, Ninsiima Victoria ${ }^{2}$, Abubakar Sunusi Adam ${ }^{1}$, Adamu Almustapha Aliero ${ }^{1,3}$ \\ ${ }^{1}$ Department of Microbiology and Immunology, Faculty of Biomedical Sciences, Kampala International University Western \\ Campus, Bushenyi-Ishaka, Uganda, P.O Box 71, Bushenyi, Uganda \\ ${ }^{2}$ School of Pharmacy, Kampala International University Western Campus, Ishaka, Uganda, P.O Box 71, Bushenyi, Uganda \\ ${ }^{3}$ Department of Biological Sciences, Faculty of Sciences, Kebbi State University of Science and Technology, Kebbi State, \\ Nigeria.
}

\begin{abstract}
Streptococcus pneumoniae is the common cause of pneumonia, meningitis, bacteremia and Septicemia among adults and children worldwide. Resistance to antimicrobials agents has been reported among S. pneumoniae which necessitate the need for alternative intervention such as ethno-medicinal plants. Cymbopogon citratus is an ethno-medicinal plant which is known to have pharmacological activities including antibacterial activity. This study aimed at determining the in vitro antibacterial activity of $C$. citratus ethanolic leaves crude extract against clinical isolates of $S$. pneumoniae. Fresh leaves of $C$. citratus were collected early in the morning; shed dried, pulverized and extracted in ethanol (96\%) using standard extraction method. The antibacterial activity, Minimum Inhibitory and Minimum Bactericidal Concentrations of $C$. citratus ethanolic leaves crude extract were determined against clinical isolates of $S$. pneumoniae. C. citratus ethanolic crude extract showed antibacterial activity against $S$. pneumoniae at $500 \mathrm{mg} / \mathrm{ml}$ concentration with mean and standard deviation zone of inhibition $(26.33 \pm 1.53$ $\mathrm{mm}$ ) in comparison with that of $250 \mathrm{mg} / \mathrm{ml}$ concentration which gave $20.33 \pm 2.08 \mathrm{~mm}$ mean and zone of inhibition. The minimum inhibitory concentration of the plant crude extract against $S$. pneumoniae was $15.63 \mathrm{mg} / \mathrm{ml}$ while the minimum bactericidal concentration was $125 \mathrm{mg} / \mathrm{ml}$. The study found that $C$. citratus leaves ethanolic crude extract was active against $S$. pneumoniae. It is recommended that studies should be done focusing on isolation of specific phytochemicals of the $C$. citratus leaves crude extract and then determines their antibacterial activity against clinical isolates of $S$. pneumoniae.
\end{abstract}

Keywords: Antibacterial Streptococcus pneumoniae; Cymbopogon citratus; Ethanolic leaves crude extract.

\section{Introduction}

Streptococcus pneumoniae belongs to the genus Streptococci which is the normal flora of the human skin and throats which is later aspirated to the lungs causing infections (Lindstrand et al., 2016). It can also be transmitted through the inhalation of infectious droplet or

\section{Cite this article as:}

I. Ntulume et al. (2019) Int. J. Appl. Sci. Biotechnol. Vol 7(1): 31-38. DOI: 10.3126/ijasbt.v7i1.22326

\section{*Corresponding author}

Ibrahim Ntulume,

Department of Microbiology and Immunology, Faculty of Biomedical Sciences, Kampala International University Western Campus,

Bushenyi-Ishaka, Uganda, P.O Box 71, Bushenyi, Uganda

Email: ntulumeibrahim@kiu.ac.ug / ibrantulume@gmail.com

Peer reviewed under authority of IJASBT

(C) 2019 International Journal of Applied Sciences and Biotechnology 
direct contact with respiratory secretions colonizing the nasopharynx leading to blood borne diseases (WHO, 2009). Sheppard et al. (2017) reported that, there about 92 serotypes of $S$. pneumoniae that contain the capsular polysaccharide. Serotypes 3 and 37 are the most common Serotypes identified to contain the polysaccharide capsule and yet involved in majority of the prevalent diseases due to $S$. pneumoniae. The polysaccharide capsule of $S$. pneumoniae is an essential virulence factor that plays a significant role in its pathogenesis. The capsule is also the target of all current licensed vaccines for S. pneumoniae, and the introduction of conjugate vaccines to common capsular types has led to a dramatic reduction in circulating vaccine serotypes and an increase in non-vaccine serotype disease (Waight et al., 2015). Pneumococcal disease is a worldwide public health encumbrance and has been cited among the main cause of high morbidity and mortality in young children and adults, in both developed and developing countries like Uganda (UNAS, 2015; WHO, 2018; CDC, 2017). The range of diseases caused by pneumococci includes severe manifestations, e.g., bacteremia, septicaemia, meningitis and pneumonia, to less serious ones, such as bronchitis, sinusitis and otitis media Sheppard et al. (2017). Lindstrand et al., 2016 and CDC, 2017 reported that, S. pneumoniae caused more than 900,000 deaths annually among children less than five years of age globally. In Uganda, acute lower respiratory tract infections are the second major cause of morbidity after malaria and the major cause of death among children less than five accounting for $25-33 \%$ of patients admitted at Mulago National Referral Hospital (Nantanda et al., 2008). The risk of pneumonia infection is increased by a number of factors, including; pathogens, environment, health systems and antibiotics resistance. Therefore, no single intervention can efficiently prevent, treat, or control pneumonia (Mathew et al., 2011). As such, predictable ways of controlling pneumonia would include; immunization against specific pathogens, early diagnosis and treatment of the disease, and improvements in nutrition and environmental living conditions (WHO, 2013). Study showed that oral amoxicillin and intravenous penicillin $G$ were equally effective in the treatment of hospitalized children with non-severe Community Acquired Pneumonia (CAP) (Atkinson et al., 2007). However, another study showed that oral amoxicillin was more cost effective for most hospitalized children with CAP (Atkinson et al., 2007). In adults and children older than five years, treatment options for moderate pneumonia in ambulatory patients include Cotrimoxazole, Amoxicillin, Doxycycline or Erythromycin. For severe pneumonia, antibiotic therapy options are parenteral Benzyl Penicillin or Chloramphenicol (UNAS, 2015; Lorgelly et al., 2010). Globally, antibiotic resistance with $S$. pneumoniae was reported to have increased in the last two decades (WHO, 2001; CDC, 2017). Pneumococcal strains have developed resistance to several antibiotics including penicillin and other groups of antibiotics causing $40 \%$ of pneumococcal diseases worldwide (Lynch and Zhanel, 2009). Antibiotic resistance is spread among Pneumococcal strains through transformation which is the uptake of the free DNA from closely related bacterial strains or species or through conjugative transposons carrying resistance genes (CDC, 2018). Development of antimicrobial resistance against commonly used antimicrobial agents has been demonstrated to be a major threat to the pharmaceutical industry (Bedos et al., 1996; Roca et al., 2015). In Uganda, according to UNAS, 2015 the prevalence of resistance of $S$. pneumoniae to older antibiotics penicillin and Cotrimoxazole is high, between 83 and $100 \%$, even though resistance may be partial in the case of penicillin. Prevalence of resistance to newer antibiotics such as rifampicin, erythromycin and cefotaxime is low and lies between 0 and $3 \%$. But the later drugs seem to be costly and cannot be afforded by common people within developing countries. These show the needs for cheaper and safe drug to face this global challenge.

Herbal therapies can therefore provide an option for treatment of infections caused by microorganisms that are resistant to synthetic drugs. According to Rego et al., 2016; Silivano et al., 2018, plants have been cited as an alternative source of remedy against drug resistant pathogens since they accumulate vital phytochemical constituents: the secondary metabolites which are produced as by-product which may/or may not be directly useful to them. Thus secondary metabolites give plants their medicinal potential some of which include; alkaloids, tannins, saponins, flavonoids, antraquinones, glycosides, volatile oils, terpenes, essential oils, resins, phenolic compound among others. C. citratus belongs to the family Poacea, herb commonly known as lemongrass, barbed wire grass and silky heads among others (Rego et al., 2016). It is a fast growing, aromatic perennial grass which is native to South India and Sri Lanka, now widely cultivated in the tropical areas of America and Asia (Manvitha et al., 2014). Freshly cut and partially dried leaves are used medicinally and are the source of the essential oil (Manvitha et al., 2014). The essential oil is commercially valuable and widely used in food technology as well as in traditional medicine. Treatment using plant-based medicine appears to be an alternative approach due to the adverse effect of synthetic drugs and emerging antibiotic resistance (Mirghani et al., 2012). Studies indicated that $C$. citratus possesses various pharmacological activities such as anti-amoebic, antibacterial, anti-filarial, anti-fungal and anti-inflammatory properties (Manvitha et al., 2014). Various other effects like anti-malarial, anti-mutagenicity, anti-mycobacterial, antioxidant, hypoglycemic and neurobehavioral have also been studied (Manvitha et al., 2014). In India the leaves of $C$. citratus are used as stimulant, sudorific, antiperiodic, and an-ticatarrhal (is a symptom usually associated with the 
common cold and chesty coughs), Bad breath, toothache while the essential oil is used as carminative, depressant, analgesic, antipyretic, antibacterial, and antifungal agent (Manvitha et al., 2014). However, no research has been done to validate the usage of $C$. citratus leaves ethanolic extract against $S$. pneumoniae, therefore, this study aimed at determining the antibacterial activity of $C$. citratus leaves ethanolic crude extract against clinical isolate of $S$. pneumoniae.

\section{Materials and Methods}

\section{Study Design}

The study was an experimental laboratory study carried out in the Pharmacognosy laboratory, School of pharmacy and Microbiology Laboratory, Department of Microbiology and Immunology Faculty of Biomedical Sciences Kampala International University to determine the antibacterial activity of $C$. citratus leaves ethanolic crude extract against clinical isolate of $S$. pneumoniae.

\section{Study Area/Sampling Site}

The study was conducted at Microbiology laboratory, Department of Microbiology and Immunology, Kampala International University, Western Campus. Fresh leaves of plant sample were collected from the local gardens in Bwegiragye Village within Ishaka Municipality-Bushenyi District $\left(00^{\circ} 32^{\prime} 19^{\prime \prime} \mathrm{S}, 30^{\circ} 08^{\prime} 40^{\prime \prime} \mathrm{E}\right)$. This is approximately 330 Kilometers (210 miles) by road, Southwest of Kampala.

\section{Plant Sample Collection and Identification}

The $C$. citratus plant were collected from the local gardens in Bwegiragye Village within Ishaka MunicipalityBushenyi District and then taken for identification by a Botanist at Mbarara University of Science and Technology. After the identification, fresh sample leaves were collected early in the morning and transported to the Pharmacognosy laboratory, Kampala International University, Western Campus in a sterile nylon bag.

\section{Preparation of Plant Material}

The collected $C$. citratus leaves samples were thoroughly washed with tap water and rinsed with distilled water. The leaves were then chopped into small pieces and shade dried to prevent evaporation and loss of the volatile oils and also to prevent degradation of phytochemicals by direct sun light. The chopped samples were spread on a dry cemented table in the Pharmacognosy laboratory under shade and turned daily to prevent fungal attack until it completely dried. The dried plant leaves were grounded using a mortar and pestle into a powder and stored in clean closed containers under room temperature until extraction was done. The powdered leaves facilitated dissolution into the solvent during extraction (Gurnani et al., 2016).

\section{Extraction of Plant Sample and Percentage Yield of Extract}

Extraction was done using maceration method as described by Gideon et al., 2012. One Hundred and fifty grams (150g) of powdered leaves sample were soaked in $500 \mathrm{ml}$ of $96 \%$ ethanol in a beaker (1L) and allowed to mix for $48 \mathrm{hrs}$ following a frequent shaking using a sieve shaker. After 24 hrs the mixture was filtered using a clean white cotton cloth followed by the use of Whatman No. 1 filter paper grade 1 of $0.5 \mu \mathrm{L}$. The filtrate was concentrated by drying in the oven (Binder, Model E28) at $40^{\circ} \mathrm{C}$. The percentage yield of extract was calculated using method described by Kumar et al., 2016. The dried crude extract was store at $4^{\circ} \mathrm{C}$ for further study (Anokwuru et al., 2011).

\section{Phytochemical Screening}

Phytochemical screening of the crude leaves extract of $C$. citratus was done to determine the presence of carbohydrates, volatile oils, phenolic compounds, flavonoids and tannins. The analysis was carried out according to standard method described by Ewansiha et al., 2012.

\section{Test Organism}

The test microorganism used in this study was a clinical isolate of $S$. pneumoniae obtained from Microbiology Laboratory, Kampala International University Teaching Hospital. The isolate was further confirmed according to methods described by Sheppard et al., 2017 for $\alpha$-hemolysis $5 \%$ defibrinated sheep blood, gram reaction, positive catalase test, negative tube coagulase test, optochin susceptibility ( $\geq 14 \mathrm{~mm}$ diameter), and bile solubility. Additional biochemical testing was performed using API Rapid ID Strep 32 (bioMérieux, Basingstoke, UK) according to the manufacturer's instructions. The isolate was then maintained on slopes of Tryptic soy broth supplemented with plasma (BBL, Cockeysville, MD) at 4 ${ }^{\circ} \mathrm{C}$.

\section{Antibacterial Activity Testing of Leaves Crude Ethanolic Extract}

Antibacterial activity of $C$. citratus leaves ethanolic crude extract was determined using agar well diffusion method according to method described by Rego et al.,2016; Gurnani et al., 2016. A sterile Mueller Hinton agar plates (Hi-Media Laboratories Pvt Ltd, Mumbai, India, M173) supplemented with 5\% defibrinated sheep blood were inoculated with the prepared suspension of the test bacteria by surface spreading using a sterile cotton swab after been standardized with $0.5 \mathrm{McF}$ arland standard. Using sterile glass cork borers, four wells of $4 \mathrm{~mm}$ depth and $6 \mathrm{~mm}$ diameter were carefully made on the agar plates without distorting the media sufficiently spaced and were sufficiently spaced. The dried crude leaves ethanolic extract of $C$. citratus was dissolved in $10 \%$ sterile dimethyl sulfoxide (DMSO) to prepare two concentrations of $500 \mathrm{mg} / \mathrm{ml}$ and $250 \mathrm{mg} / \mathrm{ml}$. Two well made in Mueller 
Hinton agar plate were each filled with $50 \mu \mathrm{l}$ of $500 \mathrm{mg} / \mathrm{ml}$ and $250 \mathrm{mg} / \mathrm{ml}$ concentration of $C$. citratus leaves ethanolic extract. The third well was filled with $50 \mu \mathrm{l}$ of $0.2 \mathrm{mg} / \mathrm{ml}$ of Amoxicillin antibiotic as positive control and the fourth with $50 \mu \mathrm{l}$ of $10 \%$ sterile DMSO as negative control. The culture plates were left for 30 minutes to allow the extracts to diffuse through the media and then incubated in Bacteriological incubator (MEMMERT TYPE BTI-26) at $37^{\circ} \mathrm{C}$ in $5 \%$ Carbon dioxide $\left(\mathrm{CO}_{2}\right)$ for 24 hours (Sheppard et al., 2017). After 24 hours of incubation, the diameters zone of inhibition of both the plant leaves ethanolic crude extract and the positive control antibiotics were measured using a metric ruler in millimeter $(\mathrm{mm})$. The zone of inhibition is the diameter of the area of no growth of the organism from the well filled with plant extract or amoxicillin antibiotic. A diameter of inhibition $>6 \mathrm{~mm}$ was indicative of susceptibility to the extract and so the MIC and MBC tests were done too.

\section{Determination of Minimum Inhibitory Concentration (MIC)}

The MIC of $C$. citratus leaves crude ethanolic extract was lowest concentration required to inhibit the growth of $S$. pneumoniae. It was determined using broth tube dilution method as described by Rachuonyo et al., 2016 with modification. A two-fold serial dilution was performed using ten sterile tubes containing $0.5 \mathrm{ml}$ of Brain Heart Infusion broth (BHI) (Hi-Media Laboratories Pvt Ltd, Mumbai, India, M210). Zero point five milliliter of 500 $\mathrm{mg} / \mathrm{ml}$ extract concentration was introduced to the first test tube containing $0.5 \mathrm{ml}$ of BHI broth and mixed thoroughly. Zero point five milliliter $(0.5 \mathrm{ml})$ of this dilution was transferred subsequently to tubes in two-fold dilution of the original extract concentration up to the last tube from where $0.5 \mathrm{ml}$ broth was discarded. A pre-pre-prepared organism suspension equivalent to $0.5 \mathrm{McF}$ arland standard of 24 hour clinical culture of $S$. pneumoniae was further diluted to obtain $1.0 \times 10^{6} \mathrm{cfu} / \mathrm{ml}$ as described by EUCAST and ESCMID, 2003. Then $0.5 \mathrm{ml}$ of organism of this concentration was added into each of the tubes that contained serially diluted extract. This formed a decreasing final dilution extract concentration of $250 \mathrm{mg} / \mathrm{ml}, 125$ $\mathrm{mg} / \mathrm{ml}, 62.5 \mathrm{mg} / \mathrm{ml}, 31.25 \mathrm{mg} / \mathrm{ml}, 15.63 \mathrm{mg} / \mathrm{ml}, 7.81$ $\mathrm{mg} / \mathrm{ml}, 3.91 \mathrm{mg} / \mathrm{ml}, 1.95 \mathrm{mg} / \mathrm{ml}, 0.98 \mathrm{mg} / \mathrm{ml}$ and 0.49 $\mathrm{mg} / \mathrm{ml}$ in each of the tubes and now with an organism concentration of $5.0 \times 10^{5} \mathrm{cfu} / \mathrm{ml}$ as described by EUCAST and ESCMID (2003; Perumal et al. (2012). Triplicates of each tube concentration were made. Two controls were prepared as follows; Control one had broth and bacteria but no extract in order to find out whether the media supported the growth of $S$. pneumoniae and whether the organism was actually viable. Control 2 had only broth and no bacterium inoculated but with extract, thus helped to find out whether the broth was contaminated with other organisms. Thereafter, the tubes were incubated at $37^{\circ} \mathrm{C}$ in $5 \% \mathrm{CO}_{2}$ for 24 hours (Koneman et al., 1997). After incubation $50 \mu \mathrm{l}$ of $0.2 \mathrm{mg} / \mathrm{ml}$ p-iodonitrotetrazolium chloride was added in all the test tubes (INT, Sigma-Aldrich, USA) and incubated at $37^{\circ} \mathrm{C}$ for $30 \mathrm{~min}$. Development of pinkish-red color in the respective tubes was indicative of bacterial growth (conversion of INT to formazan) and clear solution was suggestive of no growth. The lowest concentration of the crude extract at which there was no color change (clear) and was apparently invisible as compared to the next tube dilution was taken as the minimum inhibitory concentration (MIC) of the $C$. citratus leaves crude ethanolic extract against the test clinical S. pneumoniae clinical isolate (Rachuonyo et al.,2016; Perumal et al., 2012).

\section{Determination of Minimum Bactericidal Concentration (MBC)}

The minimum bactericidal concentration of $C$. citratus leaves crude ethanolic extract required to kill $S$. pneumoniae was determined by plating out the contents of clear tubes (tube with no visible turbidity of growth) from MIC results using sterile wire loop on sterile Mueller Hinton agar (HiMedia Laboratories Pvt Ltd, Mumbai, India, M173) supplemented with $5 \%$ defibrinated sheep blood and incubated at $37^{\circ} \mathrm{C}$ in $5 \% \mathrm{CO}_{2}$ for 24 hours. The least concentration that showed no colony growth on the plates was considered as the Minimum Bactericidal Concentration (MBC) (Tiwari et al., 2018).

\section{Data Analysis}

The measurements for inhibition zone diameters and the respective concentrations used were entered into Microsoft Excel and then exported to SPSS-20 software for analysis. One-way ANOVA was used to compute descriptive statistics of mean and standard deviation of inhibition zone diameters in mm. Tukey's post hoc test was used to obtain multiple comparisons between the antibacterial activity of plant extract, positive control and negative control. Statistical significance was considered at $\mathrm{p}$-value $\leq 0.05$.

\section{Results}

\section{Percentage Yield of Extract}

Extraction was done using $150 \mathrm{~g}$ of the powdered $C$. citratus plant leaves and yielded $5.5 \mathrm{~g}$ of dried crude ethanolic extract which was equivalent to a percentage yield of $3.667 \%$ was obtained as shown in Table 1.

Table 1: Percentage extractive yield of $C$. citratus leaves crude ethanolic (96\%) extract

\begin{tabular}{lllll}
\hline $\begin{array}{l}\text { Weight of powdered } \\
\text { plant material(g) }\end{array}$ & $\begin{array}{l}\text { Weight of extract+ } \\
\text { container(g) }\end{array}$ & $\begin{array}{l}\text { Weight of } \\
\text { container alone(g) }\end{array}$ & $\begin{array}{l}\text { Weight of } \\
\text { extract }(\mathbf{g})\end{array}$ & $\begin{array}{l}\text { Percentage } \\
\text { yield (\%) }\end{array}$ \\
\hline 150 & 108.1 & 102.6 & 5.5 & 3.667
\end{tabular}

Key: g: gram, \%: percentage. 


\section{Phytochemical Screening}

Phytochemical analysis of $C$. Citratus leaves crude ethanolic extract results showed that, the extract contained four phytochemicals compounds which included; tannins, phenolic compounds, carbohydrates, volatile oils and saponins as shown in Table 2.

Table 1: Phytochemical screening of the ethanolic leaves crude extracts of $C$. citratus

\begin{tabular}{lc}
\hline \multicolumn{1}{c}{ Phytochemical constituents } & Results \\
\hline Tannins & + \\
Phenolic compounds & + \\
Flavonoids & - \\
Carbohydrates & + \\
Volatile oils & + \\
Saponins & + \\
Steroids & - \\
\hline
\end{tabular}

Key: +: presence - : negative

\section{Antibacterial Activity of C. Citratus Ethanolic Leaves Crude Extract Against S. Pneumoniae}

The susceptibility of $S$. pneumoniae to $C$. citratus leaves crude extract was determined by agar well diffusion method where the diameter zones of inhibition in $\mathrm{mm}$ were measured after 24 hours of incubation at $37^{\circ} \mathrm{C}$ and it was done in triplicate (3times), the final results were reported as mean $\pm \mathrm{SD}$ as shown in Table 3 . The $C$. citratus leaves crude extract showed a high level of antibacterial activity with the highest mean and standard deviation inhibition zone diameters of $26.33 \pm 1.53 \mathrm{~mm}$ at $500 \mathrm{mg} / \mathrm{ml}$ concentration compared at half way concentration of $250 \mathrm{mg} / \mathrm{ml}$ which showed mean and standard deviation inhibition zone diameter of $20.33 \pm 2.08 \mathrm{~mm}$. There was a statistically significant difference $(\mathrm{p}=0.002)$ between the antibacterial activity of $C$. citratus leaves ethanolic crude extract at $500 \mathrm{mg} / \mathrm{ml}$ and $250 \mathrm{mg} / \mathrm{ml}$. The statistical analysis using one way ANOVA multiple comparison showed that at both concentrations of the extract used, there was a significant difference $(\mathrm{p}<.0001)$ between the extracts and the negative control (DMSO) which showed no inhibition zone diameter $(0.0 \mathrm{~mm})$. The positive control (Amoxicillin, $0.2 \mathrm{mg} / \mathrm{ml}$ ) showed a higher mean and standard deviation inhibition zone diameter of $40.00 \pm 0.00 \mathrm{~mm}$ compared to the $C$. citratus leaves crude extract at both concentrations used in the study. This was also statistially significant $(\mathrm{p}<0.0001)$ as shown in Table 3 and Fig. 1.

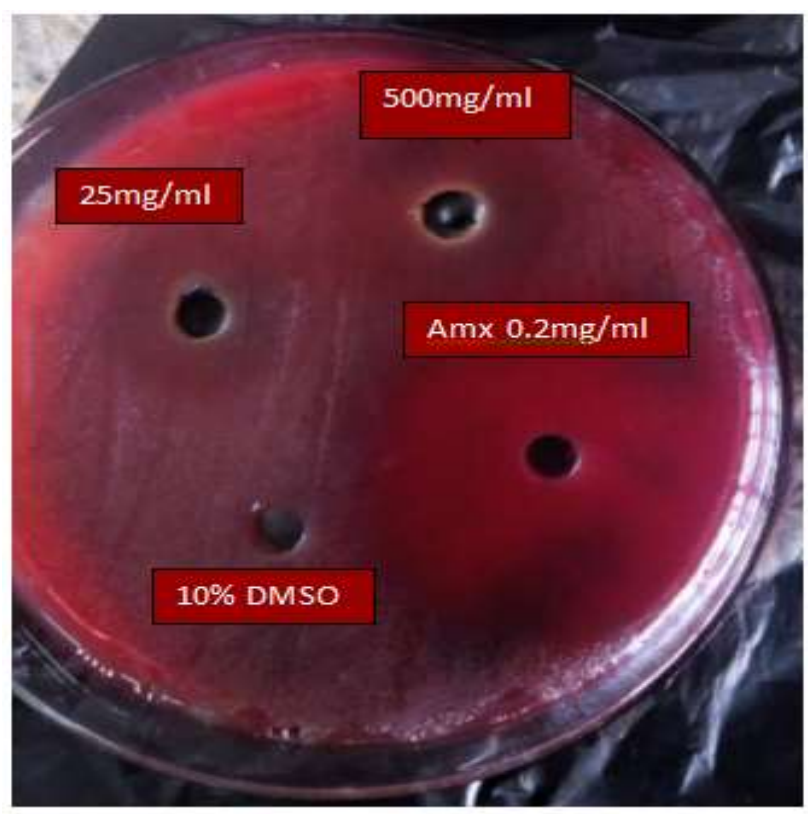

Fig. 1: Inhibition zone diameters of $C$. citratus ethanolic leaves crude extract against $S$. pneumoniae clinical isolate on $5 \%$ defibrinated sheep blood. Amx : Amoxicillin antibiotic.

\section{Determination of MIC and MBC of C. citratus Ethanolic Leaves Crude Extract}

The minimum inhibitory concentration (MIC) of the $C$. citratus ethanolic leaves crude extract against $S$. pneumoniae was $15.63 \mathrm{mg} / \mathrm{ml}$ while the minimum bactericidal concentration (MBC) of the $C$. citratus ethanolic leaves crude extract against $S$. pneumoniae was found to be $125 \mathrm{mg} / \mathrm{ml}$ Table 4 .

Table 3: Mean and standad deviation inhibition zone of C. citratus ethanolic leaves crude extract against $\mathrm{S}$. pneumoniae clinical isolate

\begin{tabular}{|c|c|}
\hline Extract and controls & Mean \pm SD inhibition zone diameter $(\mathrm{mm})$ \\
\hline Ethanolic extract, $500 \mathrm{mg} / \mathrm{ml}$ & $26.33 \pm 1.53^{\mathrm{a}, \mathrm{d}}$ \\
\hline Ethanolic extract, $250 \mathrm{mg} / \mathrm{ml}$ & $20.33 \pm 2.08^{\mathbf{a}, \mathbf{d}}$ \\
\hline Amoxicilin $0.2 \mathrm{mg} / \mathrm{ml}$ (positive control) & $40.00 \pm 0.00^{\mathbf{b}, \mathbf{c}}$ \\
\hline $10 \%$ DMSO (negative control) & $0.00^{\mathrm{e}}$ \\
\hline \multicolumn{2}{|c|}{ 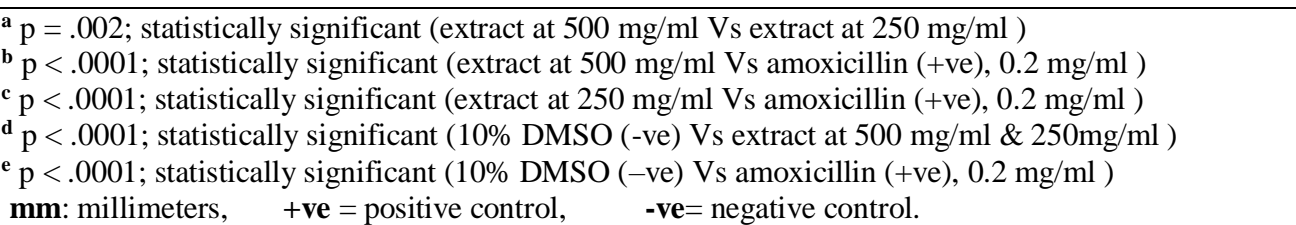 } \\
\hline
\end{tabular}


Table 4: Minimum Inhibitory Concentration and Minimum bactericidal concentration of C. citratus ethanolic leaves crude extract against S. pneumoniae

Concentrations of $C$. citratus ethanolic leaves crude extract (mg/ml)

\begin{tabular}{lccccccccc}
\hline Extract & 500 & 250 & 125 & 62.50 & 31.25 & 15.63 & 7.81 & MIC & MBC \\
Reading & - & - & - & - & - & - & + & 15.63 & 125 \\
& & & & & & & & & \\
\multicolumn{7}{l}{ Key: - Clear solution, no bacterial growth } & + Turned pinkish-red with bacterial growth.
\end{tabular}

\section{Discussion}

Plant extracts have been used for thousands of years in food preservation, pharmaceuticals, alternative medicine and natural therapies to improve the quality of healthcare. $C$. citratus extracts are potential sources of novel antimicrobial compounds especially against bacterial pathogens (Hindumathy, 2011; Ewansiha et al., 2012; Rego et al., 2016). S. pneumonia is one the superbugs commonly involved in causing severe manifestations, such as: pneumoniae, bacteraemia, septicemia and meningitis, to less serious ones, such as bronchitis, sinusitis and otitis media (Sheppard et al., 2017). Furthermore, CDC, 2018 reported that these bacteria were resistant to at least one antibiotic. However, antibacterial activity of $C$. citratus ethanolic leave crude extracts against $S$. pneumoniae has not been evaluated. In vitro studies in this work showed that the C. citratus ethanolic leaves crude extracts inhibited bacterial growth $S$. pneumoniae clinical isolate and its effectiveness varied with change in concentration.

The present study showed that $C$. citratus ethanolic leaves crude extract had significant antibacterial activity against $S$. pneumoniae clinical isolates with higher mean and standard deviation inhibition zone diameters at $500 \mathrm{mg} / \mathrm{ml}(26.33 \pm$ $1.53 \mathrm{~mm})$ compared to $250 \mathrm{mg} / \mathrm{ml}(20.33 \pm 2.08 \mathrm{~mm})$. The antibacterial activity reported in the present study was in agreement with studies done by Singh et al., 2011; Ambade and Bhadbhade, 2015 in India and in Nigeria by Ewansiha et al., 2012 although established theirs at a lower extract concentration. Rêgo et al. (2016) reported similar antimicrobial activity of $C$. citratus against Streptococcus spp biofilms. Hindumathy, 2011 reported similar findings that the $C$. citratus ethanolic leaves crude extracts inhibited the growth of standard and local strains of the organisms used. Several studies (Samy, 2005; Mitchell and Ahmad, 2006) had shown that lemon grass had strong and consistent inhibitory effects against various pathogens which are in agreement with the present study findings. The antibacterial activity exhibited by $C$. citratus leaves crude extract against $S$. pneumoniae in this study was attributed to its phytochemical composition.

Phytochemical screening of $C$. citratus leaves crude extract showed four active ingredients including; tannins, saponins, phenolic compounds and carbohydrates which were also reported in similar studies when methanol was used as the extraction solvent (Hindumathy, 2011). According to Ewansiha et al., 2012; Hindumathy, 2011 tannins and phenolic compounds have been found to inhibit bacterial and fungal growth and also capable of protecting certain plants against infection. Tannins and tannic acid owe their stringent action to the fact that they precipitate protein and render them resistant to attack by proteolytic enzymes, internally; they form a pellicle of coagulated protein over the lining of the alimentary tract (Ewansiha et al., 2012). Furthermore, Ewansiha et al., 2012 reported that there are three different types of tannins; hydrolysable tannins, Nonhydrolysable tannins or condensed tannins and Pseudo tannins that contribute to antibacterial activity of $C$. citratus extract. Liang and Yi, 2008 reported that the volatile oils which are part of the plant's phytochemicals exhibited great antibacterial activity and this confirms the potency of this particular plant against $S$. pneumoniae in this present study. Recently, there has been a considerable attention in crude extracts and essential oils from aromatic plants with antibacterial activities for preventing pathogens and toxin producing bacteria in foods Mitchell and Ahmad, 2006; Hindumathy, 2011. The results obtained in the present study were not consistent with those of Ambade and Bhadbhade, 2015 who reported a slightly higher activity against other Streptococcus spp other than $S$. pneumoniae who reported lower MIC values ranging from 10 to $2.5 \mathrm{mg} / \mathrm{ml}$ as compared in this present study. This difference in activity could probably be attributed to by differences in concentration of the active phytochemicals contained in both plants used since the plants have different environmental sources and differences in extraction procedures used in both studies (Senjobi et al., 2017). Additionally, the slight deviation from similar studies could be attributed to the genotypic characteristics of $S$. pneumoniae to express polysaccharide capsule, an essential virulence factor which could have lowered drug uptake, thus leading to the continuous resistance, varying the potent extract concentration required ${ }^{3}$. The antibacterial activity of the two plant extract concentrations used in the present study was significantly $(\mathrm{p}<.0001)$ lower than that of the positive control, $0.2 \mathrm{mg} / \mathrm{ml}$ amoxicillin. This could probably be due to the fact that the leaves crude extract may still contain some impurities which may prevent its activity compared to purified positive control at low concentration. This was in agreement to the reports by Ewansiha et al., 2012 who conducted a similar study in Nigeria. Therefore, 
purification is very important because the presence of some ingredients which reduce the activity of the bioactive components is eliminated, concentrating the active component hence, increasing the potency of the active components. However, Ewansiha et al., 2012 added that, the differences reported could probably be attributed to different extraction techniques, purification methods and susceptibility methods used before performing the antibacterial assays. This agrees with recent reports of no doubt to confirm partly that $C$. citratus has been used against gastrointestinal disturbances, but might require high dosage due to the level of antimicrobial activity it showed in the presence research results.

Furthermore, the present study showed higher MIC and MBC values as compared to similar studies which reported lower MIC values of $0.04 \mathrm{mg} / \mathrm{mL}$ although different bacteria were used and this would be suggestive for the differences (Rego et al., 2016). Furthermore, Ewansiha et al., 2012 reported slightly higher MIC values ranging from $20 \mathrm{~g} / \mathrm{ml}-26 \mathrm{~g} / \mathrm{ml}$ and MBC of $28 \mathrm{~g} / \mathrm{ml}$ against gram positive bacteria as compared to the present study.

\section{Conclusion}

The study revealed the antibacterial activity possessed by $C$. citratus ethanolic leaves crude extract against clinical isolate of $S$. pneumoniae. The antibacterial activity was attributed by the phytochemical constituents it contains, thus validating its usage in the treatment of ailments caused by $S$. pneumoniae. It's recommended that similar studies should be done focusing on isolation of specific phytochemicals of the plant and then establishes their antibacterial activity against $S$. pneumoniae.

\section{Acknowledgement}

We would like to thanks all staff of Microbiology and Pharmacognosy Laboratories of Kampala International University-Western Campus for their kind support during this research.

\section{References}

Ambade SV and Bhadbhade BJ (2015) In vitro comparison of antimicrobial activity of different extracts of Cymbopogon citratus on dental plaque isolates. Int J Curr Microbiol Appl Sci 4(7): 672-681.

Anokwuru CP, Anyasor GN, Ajibaye O, Fakoya O and Okebugwu $P$ (2011) Effect of Extraction Solvents on Phenolic, Flavonoid and Antioxidant activities of Three Nigerian Medicinal Plants. Nature and Sci 9(7): 456-472.

Atkinson M, Lakhanpaul M and Smyth A (2007) Comparison of oral amoxicillin and intravenous benzyl penicillin for community acquired pneumonia I children (PIVOT trial): a multicentre pragmatic randomized controlled equivalencetrial. Thorax 62(12): 1102-1106. DOI: $\underline{10.1136 / \text { thx.2006.074906 }}$

Bedos JP, Chevret S, Chastang C, Geslin P and Regnier B (1996) French Cooperative Pneumococcus Study Group.
Epidemiological features of and risk factors for infection by Streptococcus pneumoniae strains with diminished susceptibility to penicillin: findings of a French survey. Clinical infectious diseases 22(1): 63-72. DOI: $\underline{\text { 10.1093/clinids/22.1.63 PMid:8824968 }}$

CDC (2017) Global Pneumococcal Disease and Vaccine. Available https://www.cdc.gov/pneumococcal/global.html. Accessed 14/09/2018.s

CDC (2018) Drug Resistance: Pneumococcal Disease. Available at https://www.cdc.gov/pneumococcal/drugresistance.html. Access 14/09/2018

EUCAST and ESCMID (2003) Determination of minimum inhibitory concentrations (MICs) of antibacterial agents by broth dilution. Clin. Microbiol. Infect 91-7. DOI: 10.1046/j.1469 0691.2003.00790

Ewansiha JU, Garba SAI, Mawak JD and Oyewole OAI (2012) Antimicrobial Activity of Cymhopogon citratus (Lemon Grass) and Its Phytochemical Properties. Frontiers in Science 2(6), 214-220

Gideon I, Ogu W, Omotola T, Perpetua U, Nwachukwu B and Esegbuyota I (2012) Antimicrobial and phytochemical evaluation of the leaf, stem bark and root extracts of Cyathulaprostrata (L) blume against some human pathogens. J. Intercult Ethnopharmacol 1(2): 35-43.

Gurnani N, Madhu G, Rakesh S, Darshana M and Bhupendra KM (2016) Effect of extraction methods on yield, phytochemical constituents, antibacterial and antifungal activity of Capsicum frutescens L. Indian Journal of Natural Products and Resources 7(1): 32-39.

Hindumathy CK (2011) In-vitro Study of Antibacterial Activity of Cymbopogon citratus. International Journal of Biotechnology and Bioengineering 5(2): 48-52.

Koneman EW (1997) The Gram-positive cocci. Part II: Streptococci, Enterococci, and Streptococcus-like bacteria. Color atlas and textbook of diagnostic microbiology. 577-649.

Kumar P, Kumar J, Kumar R and Dubey RC (2016) Studies on phytochemical constituents and antimicrobial activities of leaves, fruits and stems of Solanum nigrum L. Asian Journal of Plant Science and Research 6(4): 57-68.

Liang LZ and Yi M L (2008) HPLC, NMR, and M. S. MALDITOF. "Analysis of condensed tannins from Lithocarpus glaber leaves with potent free radical scavenging activity. Liang Molecules 13: 2986-2997. DOI: $\underline{10.3390 / \text { molecules } 13122986}$

Lindstrand A, Kalyango J, Alfvén T, Darenberg J, Kadobera D, Bwanga F and Källander K (2016). Pneumococcal Carriage in Children under Five Years in Uganda-Will Present Pneumococcal Conjugate Vaccines Be Appropriate? PloS one 11(11): DOI: 10.1371/journal.pone.0166018.

Lorgelly PK, Maria A, Monica L, Alan RS, Harish V, Vivienne W and Terence S (2009) Oral versus I.V antibiotics for CAP in children: a cost-iniisation analysis. Eur Respir 
Jounal 35(4): $\quad 858-864 . \quad$ DOI:

10.1183/09031936.00087209.

Lynch JP and Zhanel GG (2009) Streptococcus pneumoniae: does antimicrobial resistance matter?. In Seminars in respiratory and critical care medicine. Thieme Medical Publishers 30(02): 210-238.

Manvitha K and Bidya B (2014) Review on pharmacological activity of Cymbopogon citratus. International Journal of Herbal Medicine 1(6):5-7

Mathew JL, Patwari AK, Gupta P, Shah D, Gera T, Gogia S and Menon S (2011) Acute respiratory infection and pneumonia in India: a systematic review of literature for advocacy and action: UNICEF-PHFI series on newborn and child health, India. Indian pediatrics 48(3):191. DOI: 10.1007/s13312-011-0051-8

Mirghani MES, Liyana Y and Parveen J (2012) Bioactivity analysis of lemon grass (Cymbopogon citratus) essential oil. International Food Research Journal 19(2): 569-575.

Mitchell MH and Ahmad 1 (2006) A Review of Medicinal Plant Research at the University of the West Indies, Jamaica, 1948-2001. West Indian Med J. 55 (4): 243.

Nantanda R Hildenwall H Kaddu MSD Kalyesubula I Tumwine JK (2008) Bacterial aetiology and outcome in children with severe pneumonia in Uganda 28: 253-260.

Perumal S Pillai S Cai LW Mahmud R Ramanathan S (2012) Determination of minimum inhibitory concentration of Euphorbia hirta (L.) extracts by tetrazolium microplate assay. Journal of Natural Products 5(2): 68-76.

Rachuonyo HO, Ogola PE, Arika WM, Kiboi NG and Wambani J R (2016) Antimicrobial Potency of Methanolic Leaf Extracts from Selected Medicinal Plants against Staphylococcus aureus. J Med Microb Diagn 5(219), 2161-0703.

Rego CB, Silva AM, Gonçalves LIM and Paschoal MAB (2016) In vitro antimicrobial activity of essential oil of Cymbopogon citratus (lemon grass) on Streptococcus mutans biofilm. African Journal of Microbiology $\begin{array}{llll}\text { Research } & \text { 10(31): } & 1224-1228 . & \text { DOI: }\end{array}$ 10.5897/AJMR2016.8216

Roca I, Akova M, Baquero F, Carlet J, Cavaleri M, Coenen S and Kahlmeter G (2015) The global threat of antimicrobial resistance: science for intervention. New microbes and new infections 6: 22-29. DOI: $\underline{10.1016 / j . n m n i .2015 .02 .007}$

Samy RP (2005) Antimicrobial activity of some medicinal plants from India. Fitoterapia 76: 697-699. https://doi.org/10.1016/i.fitote.2005.06.011

Senjobi CT, Ettu AO and Otujo CO (2017) Antibacterial and antifungal activities of leaf extracts of Phyllanthus amaru Schum and Thonn. Journal of Pharmacognosy and Phytotherapy 9(1): 6-10. DOI: 10.5897/JPP2013.0261

Sheppard CL, Kapatai G, Broughton K, Schaefer U, Hannah M, Litt DJ and Fry NK (2017) Clinical Streptococcal isolates, distinct from Streptococcus pneumoniae, but containing the $\beta$-glucosyltransferase tts gene and expressing serotype 37capsular polysaccharide. Peer J 5: e3571. DOI: 10.7717/peerj.3571

Silivano N, Ntulume I, David O, Adam AS, Katabazi A, Tirwomwe M, Onchweri AN, Reagan M, Blessing YJS, Abraham B, Ambrose S, Richard B and Aliero AA (2018) In-vitro Anti-bacterial Activity of Ethanolic and Aqueous Leaf Crude Extracts of Solanum Nigrum (Black Night Shade) of Bushenyi District - Uganda on Selected Enteric Bacteria. International Journal of Innovative Approaches in Science Research 2(4): 112-125. DOI: 10.29329/ijiasr.2018.173.1

Singh BR, Singh V, Singh RK and Ebibeni N (2011) Antimicrobial activity of lemongrass (Cymbopogon citratus) oil against microbes of environmental, clinical and food origin. Int Res J Pharm Pharmacol 1(9): 228236.

Tiwari BS, Ankola AV, Sankeshwari RM, Bolmal U and Kashyap BR (2018) Comparison of Antibacterial Efficacy of Aqueous Suspension, Alcoholic Extract and their Combination of Stevia rebaudiana against two Cariogenic Organisms-An in-vitro study. Int. J. Life. Sci. Scienti. Res (1716): eISSN, 2455. DOI:10.21276/ijlssr.2018.4.4.13

UNAS (2015) Antibiotic Resistance in Uganda: Situation Analysis and Recommendations, ISBN: 978-9970-424-10-8. A4 Lincoln House Makerere University P.O. Box 23911, Kampala, Uganda.

Waight PA, Andrews NJ, Ladhani SN, Sheppard CL, Slack MP and Miller E (2015) Effect of the 13-valent pneumococcal conjugate vaccine on invasive pneumococcal disease in England and Wales 4 years after its introduction: an observational cohort study. The Lancet infectious diseases 15(5): 535-543. DOI: 10.1016/S1473-3099(15)70044-7

WHO (2018). Antibiotic resistance. Available online http:/www.int/mediacentre /factsheets/antibioticresistance/en/. Accessed 21/5/2018

World Health Organization (2001) WHO Model Prescribing Information: drugs used in bacterial infections. World Health Organization. Available at apps.who.int/medicinedocs/en/d/Js5406e/. Accessed $13 / 4 / 2018$.

World Health Organization (2009). Global literature review of Haemophilus influenzae type $\mathrm{b}$ and Streptococcus pneumoniae invasive disease among children less than five years of age. 58(18): 1980-2005. https://www.cdc.gov/mmwr/pdf/wk/mm5818.pdf

World Health Organization, Unicef (2013) Ending preventable child deaths from pneumonia and diarrhoea by 2025: The integrated Global Action Plan for Pneumonia and Diarrhoea (GAPPD). Available at https://www.who.int/woman_child__ accountability /news/gappd_2013/en/. Accessed 27/3/2018 